\title{
Producing Journalistic News Satire : How Nordic Satirists Negotiate a Hybrid Genre
}

\section{Koivukoski, Joonas}

2020-04-25

Koivukoski , J \& Ödmark, S 2020 , ' Producing Journalistic News Satire : How Nordic

Satirists Negotiate a Hybrid Genre ' , Journalism studies , vol. 21 , no. 6 , pp. 731-747 . https://doi.org/10.1080/1461

http://hdl.handle.net/10138/332835

https://doi.org/10.1080/1461670X.2020.1720522

unspecified

acceptedVersion

Downloaded from Helda, University of Helsinki institutional repository.

This is an electronic reprint of the original article.

This reprint may differ from the original in pagination and typographic detail.

Please cite the original version. 


\title{
Producing Journalistic News Satire: How Nordic Satirists Negotiate a Hybrid Genre
}

\begin{abstract}
Political satire is an elusive hybrid genre that through its evolution over the past two decades has gained both media and scholarly interest. Inspired by American TV shows like Last Week Tonight, a new wave of more journalistic news satire has spread across the world. Studies have scrutinized its contents and effects, but the production side has remained largely uncovered. This study applies the concepts of genre and boundary work to analyze how advocates of this practice relate themselves to news journalism and previous satire. Based on qualitative interviews with 16 key production team members of four topical satire programs, we investigate how Nordic news satirists interpret their aims and work routines. We argue that both Finnish and Swedish news satirists embrace some of the traditional values of journalism such as striving for factuality, political relevance, and monitoring the powerful while they simultaneously aim for more emotional, opinionated, and exaggerated expression than in regular news reporting. The implications of this hybrid, "neomodern" ethos are examined.
\end{abstract}

Keywords: satire, infotainment, comedy, interview studies, political humor, hybridity

\section{Introduction}

The early 2000s marked a new era in political satire as new kinds of hybrid programs emerged that combined political entertainment with journalistic contextualization (Baym 2010; Gray, Jones, and Thompson 2009; Jones 2010). The undeniable flagship of this development was The Daily Show with Jon Stewart (TDS, Comedy Central, 1996-2015), that evolved from lighthearted late-night entertainment to biting topical satire (Hersey 2013). The program was different from previous infotainment programs, comedies, and satire shows on the grounds that it provided more contextualization (Fox, Koloen, and Sahin 2007) that enabled more substantial critique of politics and media (Baym 2005; Jones 2010). TDS inspired several successors; indeed, the spin-off Last Week Tonight with John Oliver (LWT, HBO 2014-) was found to be even more similar to traditional news journalism in that it generated its own stories that were not dependent on the material produced by the gatekeepers of the press (Fox 2018). Concepts such as advocacy satire (Waisanen 2018), satiric journalism (Fox 2018), and civic journalism (Faina 2012) have been proposed to address this development. In this article, we explore how Finnish and Swedish satirists producing this genre make sense of their work.

We will use the concept of journalistic news satire to refer to a type of satire similar to TDS and LWT in that it includes politically current main stories that are well-contextualized and factual. Journalistic news satire is thereby separated from other news satire programs such as Saturday Night Live (NBC, 1975-) or Have I Got 
News for You (BBC, 1990-). The genre of journalistic news satire has been studied from various perspectives. Effects studies show that people do learn from this type of satire, but the amount of learning depends on how people perceive the content: as news, entertainment, or both (Feldman 2013; Young and Hoffman 2012). Quantitative and qualitative content analyses have made efforts to open up the peculiar hybridity of the genre, concluding that its main stories are like hard news in their topics and focus, but differ from them in their style by combining both personal and impersonal and emotional and neutral reporting (Brewer and Marquardt 2007; Fox et al. 2007; Fox 2018; Wiesman 2011; Ödmark 2018). Many have thus argued that TDS could serve as a new kind of political, civic or investigative journalism (Baym 2005; Faina 2012; Fox 2018; Hersey 2013; Peters 2013; Young 2012). Yet some scholars have warned that constant critique of politicians and journalists might lead to a withering of trust in citizens toward politics and the democratic system (Baumgartner and Morris 2006; Hart and Hartelius 2007).

Despite wide interest in the genre, few have explored the self-perceptions of the satirists themselves (see however Dagnes 2012; Smith 2016; Young 2012). Moreover, the new wave of journalistic news satire reaches outside the North American borders (e.g., Boukes 2018; Koivukoski 2019; Ödmark 2018). Based on interview data from Finland and Sweden, the current study explores the production side of journalistic news satire: how producers, presenters, and writers with a background in journalism and/or comedy interpret their work in relation to traditional news journalism and other forms of satire. By applying the concepts of genre and boundary work, we show how Finnish and Swedish news satirists share a fairly united understanding of their role. We indicate how Nordic news satirists identify with the TDS type of satire and differentiate their shows from other Nordic satire based on more substantial contextualization. Nordic news satirists have a multifaceted relationship to the concept of journalistic objectivity; they adhere to factuality, topical relevance, and political independence, but also aim for emotional, opinionated, and exaggerated expression. This clarifies the ways journalistic news satire is similar to and different from hard and soft news (Reinemann et al. 2012) in its aims. Overall our analysis suggests that the practices of journalism and comedy blend together in news satire, creating a hybrid genre: journalistic news satire.

\section{Journalistic News Satire as a Hybrid Genre}

The blurring of boundaries between entertainment, politics, and journalism is a recurring topic in political communication research. Journalistic news satire is an intriguing example of this hybridization. Over the years TDS, for example, has been characterized as fake news, editorial column, traditional satire, civic journalism, "infoenterpropagainment," or news parody, each definition emphasizing different aspects of the content. Hybridization is indeed a multidimensional phenomenon consisting of blurring of boundaries on the levels of text, genre, media type, work routines, and public discourse, and phrases like softening of political communication and tabloidization have been used as umbrella terms to capture this complexity (e.g., Otto, Glogger, and Boukes 2017). 
A genre is a class or type of text, and a hybrid genre means representations that mix characteristics of two or more genres in a way that produces an ambivalent genre status, which may lead to the development of a new genre (Mäntynen and Shore 2014). A journalistic genre can also be understood more broadly as a social practice entailing interlinked conceptions of aims, work practices, and modes of display (Hermann 2016). Social practices are routinized ways of behaviour consisting of various interconnected elements such as know-how, emotions, and motivational knowledge (Reckwitz 2002). These routines are maintained through repetition, and they change gradually through mundane crises. For media producers and audiences, genres provide schemata, frames of reference for making sense of experiences and expectations that are constantly formed and reformed between the individual and the structural and social conditions (Bruun 2010).

Satire is an ancient discursive practice that has combined critical mockery and humor in various ways over the centuries (Condren 2012; Griffin 1994). Satire can be understood as pre-generic and parasitic, because it often exploits and manipulates a diversity of genres (Peifer and Lee 2019). Satire has arguably not been professionalized in the same manner as journalism, and thus does not involve equally established practices or codes of conduct. As previously stated, journalistic news satire developed at the turn of the millennium in the US, from the rather traditional entertaining late-night show to its current form (Hersey 2013), fostering notable spin-offs such as The Colbert Report and Full Frontal with Samantha Bee.

Infotainment is an often-used umbrella concept for programs that combine politics and entertainment, including satire. However, the distribution between information and entertainment within infotainment can differ substantially (Boukes 2019). The unprecedented contextualization within the main stories in TDS (Fox et al. 2007) and LWT (Fox 2018) offer good examples at the other end of the aforementioned continuum. Hard news versus soft news has been another central conceptualization in discussions on the blurring of boundaries. Perhaps the most common distinction between the two has been topical (Otto, Glogger, and Boukes 2017): hard news deals with politics, the economy, and societal problems, and soft news entails topics such as sports, weather, and entertainment. Other forms of differentiation have included stylistic features and ways of framing. However, as most news entail elements from both, current research has moved beyond a one-dimensional and dichotomous understanding to more multidimensional analyses of modes of presentation (e.g., Otto, Glogger, and Boukes 2017; Reinemann et al. 2012).

Content analyses of TDS have shown that its main stories mostly deal with domestic and foreign politics, lifestyle, and the press, mainly excluding crime and accidents (Brewer and Marquardt 2007; Pew 2008). Moreover, an episode of TDS contained as much information as traditional broadcast news reports on the presidential elections in 2004, while the main stories in fact devoted more time to covering the campaign than traditional news (Fox et al. 2007). Yet when presenting these issues, the host of TDS constantly switches between humorous and serious framing (Wiesman 2011), showing emotion and personality, like when talking to a friend (Faina 2012). There is also some variation within journalistic news satire: TDS includes more jokes than substance (Fox et al. 2007) and, as a nightly show, mostly reacts to news, while 
LWT, as a weekly show, includes on average the same quantity of facts and jokes and produces its own main stories (Fox 2018). Thus, we can conclude that the main stories in journalistic news satire are similar to hard news in their topic selection, but differ from it by blending emotional and neutral framing, and personal and impersonal reporting. This kind of hybridity has challenged traditional dichotomies between serious content and entertainment, real and fake news, and high- and lowbrow culture.

\section{Boundary Work around Journalistic News Satire}

New hybrids developing near the journalistic field often foster normative debates on what journalism is or should be, and who can be a journalist. This metajournalistic discourse produces evaluative distinctions and identifications, also known as conceptual boundary work (Carlson 2016; Gieryn 1983; Lamont and Molnár 2002). In the study of journalistic news satire, conceptual boundaries around journalism and entertainment have been analyzed through interpretations by reporters (Berkowitz and Gutsche 2012; Feldman 2007; Tenenboim-Weinblatt 2009) and audiences (Doona 2016; Edgerly 2017; Rottinghaus et al. 2012). In this study we apply the concept boundary work to analyze how news satirists themselves relate their programs to news journalism and previous satire. In this context we understand boundary work as an active and contextual interpretation of a blended genre (Doona 2016), entailing vocabulary, definitions, distinctions, and legitimization used to grasp this hybridity (Carlson 2016).

The success of TDS has made journalists ponder the limits and possibilities of journalism in relation to entertainment (Feldman 2007). Between 1999 and 2007, Stewart's position in the journalistic field changed from an unknown outsider to first as a source of political commentary, then to an intruder, and finally as a cultural authority (Tenenboim-Weinblatt 2009). North American news satirists have themselves emphasized being only comedians (Young 2012). According to Stewart, TDS should not follow any news standards but to make people laugh (ibid.). Yet Stewart has often criticized traditional news journalism (Fox and Steinberg 2019). Researchers, based on press interviews (Young 2012) and the content of the programs, have thus aimed to analyze the ways in which TDS and LWT are a new kind of journalism (Baym 2005; Faina 2012; Fox 2018; Hersey 2013). Central to these arguments is that journalistic news satire contextualizes societal issues and criticizes the powerful in an easily understandable manner without a fixation on balanced reporting. From the perspective of boundary work, these kinds of characterization legitimate the status of TDS in the journalistic field. During the 2000s and 2010s, this type of news satire spread around the world, and countries such as Germany, The Netherlands, Canada, Australia, Mexico, Iraq, Egypt, Israel and Syria acquired national adaptations.

\section{Nordic News Satire}


Scholars have followed the trend of journalistic news satire in the US (e.g., Baym 2010; Jones 2010). This study broadens the perspective by collecting its data from outside American borders. Sweden and Finland are two Nordic welfare states. The Nordic context has a strong presence of public service broadcast formats, along with a few large private media companies. The public institutions are required to be impartial and operate in the interest of the public good through upholding good journalistic practice. Both countries are defined as representative of the democratic-corporatist model (Hallin and Mancini 2004). Finland and Sweden also both have multi-party parliaments and coalition governments, and rich histories of satire dating back to the eighteenth century at least (Kivistö 2007).

Similar to the US (Gray, Jones, and Thompson 2009), the overall picture in Finnish (Valaskivi 2002) and Swedish (Bolin 2014) TV is that since the liberalization of media markets in the 1980s, more critical and complex forms of political entertainment have emerged. The four political satire programs chosen in this study are among the most influential and popular satire shows within the two countries in recent years. They were chosen to represent different production prerequisites (public service versus commercial, larger resources versus smaller resources), but with similar objectives: regular comedic commentary on news, politics, and current affairs. Three are TV satire shows and one an audio podcast. All the programs studied represent the journalistic or neomodern wave of topical satire (Baym 2010; Hersey 2013).

The Swedish public service broadcasting show Svenska Nyheter (2018-) is a half-hour TV show similar to the American format Last Week Tonight, where a studio host satirizes news and current affairs in front of a live audience. The Finnish public service broadcasting show Noin viikon uutiset (2014-2017) aired weekly for 25 minutes and was recorded in front of a live audience. Similar to TDS and Last Week Tonight, each episode entailed a satirical news bulletin, one or two main stories, and an interview. The Finnish commercial show Uutisraportti (2014-2017) ran weekly, usually for 15-20 minutes, and was published online through HSTV, the online TV component of Helsingin Sanomat (the largest newspaper in circulation in the Nordic countries). It also aired on TV (Nelonen) during the autumn of 2015. Structurally the show was similar to Noin viikon uutiset, but it did not usually include an interview and was presented in a studio without an audience. The Swedish commercial show Lilla Drevet (2013-2018) was an hour-long audio podcast available for download or stream, associated with the tabloid Aftonbladet (the largest newspaper in Scandinavia) but independently produced. It aired weekly and consisted of a fixed panel of satirists commenting on news, politics, and societal issues in an entertaining manner.

We will examine the Nordic case of journalistic news satire using the following research questions:

RQ1: How do Nordic satirists view journalistic news satire as a genre in relation to news journalism and other forms of satire?

RQ2: How do Nordic satirists describe their aims and work routines in relation to news journalism? 
The research questions will be answered in the results, with one section designated for each question.

\section{Methodology}

To investigate how Nordic news satirists interpret their work in relation to news journalism and other forms of satire, a series of semi-structured interviews were conducted. In total, 16 people were interviewed in depth: eight Swedish and eight Finnish satirists working for four different news satire programs, one public service broadcasting program and one commercial program from each country. The most prominent producers, writers and presenters of the shows were approached, and the interviews were conducted either in person or over the phone, ranging in length from about an hour to three hours. Although having somewhat different titles and work responsibilities, all the interviewees were involved, for one's part, in producing news satire and are therefore called satirists in this article. The interviews were recorded with the permission of the participants and transcribed with relevant quotes translated into English. The Finnish interviews were conducted in 2016 and the Swedish interviews in 2018. A list of the participants' professional roles and main backgrounds can be found in Appendix A.

The overarching subjects for the interviews were news satire as a genre and the aims and work routines in their productions. Those interviewed were allowed to reflect freely upon these subjects, but with the help of prepared thematic questions based on a previous study (Koivukoski 2019). Therefore, the Finnish and Swedish interviews followed a similar structure. The interviewees were asked to provide information on their professional backgrounds and career paths, describe their current roles and work routines, reflect on journalistic news satire as a genre and the politics of journalistic news satire, and voice their views on target audiences and feedback. Specific questions included inquiries such as: Who are your role models? How do you relate your work to the concept of objectivity? Do you want to influence people? If so, in what way? Semi-structured interviews are suitable for investigating both explicit and tacit conceptions of work practice that might be exposed through systematically listening to the people involved (Schultz 2007). Moreover, by interviewing we can collect data on not only behavior but also representations-how people make sense of their activities and themselves in relation to others (Lamont and Swidler 2014). An insider view is an important part of understanding any human endeavor (e.g., Patton 1980), and specifically the underresearched field of media and satire production (Bruun 2010). Our analysis thus provides access to nonpublicly available knowledge. This 'backstage' view complements our understanding of journalistic news satire that is based on media system, content, and audience analysis.

The interview material was analyzed with qualitative content analysis. Because we were interested in how satirists themselves perceive their work routines and relation to news journalism and previous satire, we 
created themes and types accordingly. The process of identifying repetition and commonalities and differences was collaborative after key sections of the Swedish and Finnish interviews had been translated into English. First, we went through the material and coded tentative general themes such as aims, work routines, hybridity, relation to journalism, relation to satire, and sub themes such as objectivity and possible effects. After this, we summarized our interpretation of the material to two main themes: news satire as a hybrid genre, and aims and work routines.

Finally, we compared our themes to our theoretical frameworks. Theorizations of journalistic objectivity (Westersthål 1984) and genre (Bruun 2010; Hermann 2016) enabled us to scrutinize the epistemic ideals and work routines of news satirists. Through Reinemann and colleagues' (2012) multidimensional framework, we analyzed how the conceptions by news satirists were similar to and different from hard and soft news. We also paid special attention to the boundary work (Carlson 2016; Gieryn 1983; Lamont and Molnár 2002)— the conceptual identifications and distinctions made by those interviewed in relation to traditional news journalism and other forms of satire. During this part of the analysis, we discussed the conceptualizations and adjectives ascribed to the news satire genre, and reached the conclusion that it is useful to understand journalistic news satire as a sub-genre of its own.

As with any research method, interviews come with some limitations. Based on our material, we cannot directly say how the interviewed satirists conduct their work, what kind of content their programs entail, or how they affect audiences. Moreover, we cannot tell if those interviewed left some things unsaid. However, we can explore their viewpoints and experiences as they chose to express them. The fact that the study consists of three TV shows and one audio show could be seen as both a limitation and a strength. The audio podcast is dissimilar from the other shows in terms of method of presentation and technical resources. This adds a different perspective, which widens understanding of the satire scene as a whole in the Nordic context. Although not as comparable in format, we argue that the podcast satirists fill a similar space in the media environment, providing satirical and entertaining takes on well-contextualized and factual topics.

In presenting the results, the participants were given abbreviations based on their country of origin $(\mathrm{F} / \mathrm{S})$, the type of show they were associated with (PSB/C), and an added serial number for differentiation (1-8). For example, the interview participant referenced as FPSB2 is a Finnish satirist, working for public service broadcasting, being the second of eight Finnish interviewees, while SC7 is a Swedish satirist, associated with a commercial show, identified by the number seven.

\section{Results: Boundary Work and Hybridity}


Altogether, the interviewed satirists made quite clear boundaries in relation to news journalism and other forms of satire, although they also found similarities. All, more or less, acknowledged the hybrid nature of their shows. Their news satire was differentiated from news journalism on the basis that it included humor, stronger interpretation, and a position to an issue. Accordingly, the most similar genre in journalism was said to be culture journalism or opinion journalism such as editorials. The form was conceptualized more like a column or an informal essay than a news text. However, the previously mentioned conceptualizations of news satire related to journalism (Baym 2005; Faina 2012; Fox 2018; Hersey 2013) would be met with some resistance. Several of the interviewees pointed to humor and entertainment as focal points of their work, and would not call their shows journalism. Still their programs, and especially the main sections of the shows, were perceived similar to news journalism in that they considered politically current topics with factual background.

The comedians are a majority and the humor goes first, but I would never let anything through that is incorrect. [...] This is a satirical news show; I would definitely define it as a news show. (SPSB2)

As with literary satire (Griffin 1994; Kivistö 2007), the interviewed satirists claimed their aim to be both funny and critical. Yet their programs were differentiated from previous Finnish and Swedish satire based on substantial contextualization and critical insights. Their own programs were pictured as hybrids, where professional boundaries were getting increasingly blurred. Despite being an infotainment program, the Finnish commercial show was a nominee for "Journalistic Deed of the Year," resembling the Peabody awards granted to TDS for accomplishments in broadcast journalism (Hersey 2013). Some of the production team members had both journalistic and comedic work experience. A Swedish satirist expressed ambivalence toward his job title:

Of course I want it to be funny, I try to be funny, so it is partly humor, but I don't know. I had never thought of it as culture journalism before, but earlier this year I got a culture journalism award and I thought it had some truth to it. Maybe the ideas I have are ideas you could elaborate on in the culture pages of a newspaper. They are the same type of ideas. (SC6)

The practice of journalists and comedians working closely together also resulted in an increased hybridization between the two types of professionals. Having an editorial staff that consisted of both those with purely journalistic backgrounds and those with purely comedic backgrounds made for a work environment where there was an exchange of skill. It was described as an interplay that escalated over time. At first the journalists were said to be "the brakes" (SPS4), meaning the more hesitant, but they had become more comfortable with the format over time. The interplay was said to have made the journalists funnier and the humorists more journalistic. Still, the expertise of both professions was exploited in the distribution of labor: journalists did most of the investigative work and comedians wrote the jokes. Then routinely these 
people came together for selecting topics, as well as for developing punchlines and dramaturgy for the current show at hand.

Often our discussions are like: "Hey, why did this guy say this? I see what s/he's up to, but why?" And then we try to understand why somebody is so excited or angry about something as the mission for journalists and satirists is kind of to expose what is behind the curtain. The means are different, but both... aim to expose how things function. (FC3)

Studies beyond the North American news satire have also noted how journalism and satire share this 'watchdog' ethos (Koivukoski and Zareff 2018; Lockyer 2006; Zareff 2012), covering how satirists can include journalistic elements in their work and vice versa (Peifer and Lee 2019).

The trend of more substantial political humor and news commentary, inspired mostly by North American formats, was recognized in the interviews. Named as inspirations were previously mentioned shows such as The Daily Show, Last Week Tonight with John Oliver, and Full Frontal with Samantha Bee. Some members of the Finnish public service program even visited the recordings of Last Week Tonight, and the head writer of the Finnish commercial show mentioned transcribing bits from the show for getting the right balance of substance and comedy. Older and more traditional types of Finnish and Swedish satire could in comparison be categorized and dismissed as "wig satire" (SPSB3): a type of comedy less concerned with societal issues and political topics and more focused on doing funny fictional characters or impersonations. This kind of satire had its own merits as entertainment, but lacked journalistic competence and was perceived as having low interest in providing informative content.

One aspect of hybridity in producing the genre was the experienced tug-of-war between being informative and being entertaining. Tackling societal issues through a humorous lens required a distinct sense of balance, according to those interviewed. Having a mix between "nonsense and substance" was a recurring emphasis. Substance meant factual contextualization and critical insights, while nonsense entailed carnivalization of the news through witticisms such as comparisons, hyperbole, coarse language, allusions, and ironic and sarcastic remarks. A critical insight could be either a new insight to some topical issue or a more or less already known idea that was dressed up in satirical form. Although many respondents expressed that entertaining the audience was the premier goal, they emphasized that humor and critical insights were mutually supportive.

Primarily it [the main section] has to be funny. Secondly, to be funny, one has to provide a background too, so that people can laugh at it. And thirdly, it would be good to have a perspective and a point, which many others might have thought—or that nobody has ever thought. (FPSB1)

According to audience studies, people who like TDS watch it because it is funny or amusing, but also because it makes news more meaningful (Doona 2016; Edgerly 2017; Rottinghaus et al. 2012). These audiences feel that TDS provides news in an understandable, funny, and in-depth manner. Some audiences, 
however, are disappointed with what they perceive as sensationalist forms of journalism, or find TDS unconvincing because it constantly makes fun of conservatives. These two audiences do not accept mixing news and entertainment, as it violates their conception of news as a serious format (Edgerly 2017).

In recent years, Danish TV satire has been trying to reinvent itself by adopting a critical stance toward traditional news journalism (Bruun 2012). The genre of news parody can in itself be seen as a commentary on the social authority of the news (Druick 2009). Although those interviewed were generally satisfied with the news media in Finland and Sweden, this tendency to critique the media was also represented. For instance, frustration with a perceived lack of interest from the press for certain important societal topics, like climate change or the politics of the European Union, was mentioned. It was suggested that criticizing legacy news organizations was something the satire shows should do even more, because of the role of the media as a traditional power broker.

Your starting position is that you trust established media, and want to keep doing that. Mine is at least. So I know I have criticized established media a few times. Because I hold them to higher standards. (SC7)

'Higher standards' mostly related to aspects such as fact-checking and contextualization. Being critical toward colleagues could also be a way of showing independence and integrity, especially for the public service satirists. One aspect of wanting to be an alternative to legacy news media was expressed as not wanting to participate in the same daily news cycle as everyone else. The satirists should instead offer new insights from an outside perspective.

\footnotetext{
When everyone is angry at someone, and there's a media storm, and then there are some people who are contrarian and go against the PC consensus, then they are braver and more interesting. But maybe they too are owned by it, they are just followers of the flow and reacting to it. So the best thing can be to stand completely outside of it, to find something of your own. [...] Instead of running with the flow or running against the flow you can just keep yourself out of the flow. (SC6)
}

The newly emerging medium of podcasting was specifically mentioned as something opening up for this. The freedom and simple technology of podcasting had led to a vitalization of the media market, and it was allowing new voices to participate in the scene.

\section{Aims and Work Routines in Relation to News Journalism}

A central theme in the interviews was the relationship between news satire and news journalism. The interviewed satirists reflected on the similarities and differences of these practices, emphasizing how their journalistic and institutional backgrounds in media organizations posed some requirements for factuality, 
balance, and justification. Along with being entertaining, there was a need to strive for providing information, a wider picture, and political relevance. At the same time, however, the format provided room for more emotional, opinionated, and exaggerated expression.

Many interviewed stated that coming up with a point or an insight to the main topic was essential for the dramaturgy and the work process. The production teams somewhat relied on traditional news media for material, and choosing topics was to a degree a collaborative process for journalists and comedians. They described a search for a particular narrative structure.

One could call it some sort of brainstorming where we go through topics and select something.... One of the biggest challenges is to have some sort of plot. (FPSB3)

Realization of a pattern could be described as an illuminating experience: as soon as they had some sort of hunch for the insight, they could start building the story around it, gathering contextualization via news clips and writing jokes in between. The insights could range from exposing hypocrisy and irrationality to criticizing framings of political actors and providing an alternative perspective to public discussion. Being insightful in satire means aiming to clarify and analyze issues (Griffin 1994). Mentioned in the interviews were two common strategies for this: constructing an ironic narrative and arguing using humor. Constructing an ironic narrative meant that the host set a direction for a 'normal' news report and then pretended not to know that someone or something had been immoral and/or irrational. This kind of dramaturgy, where the host acts surprised by the unraveling of events, also commonly used in TDS by Stewart, was popular in the Finnish private sector show. Arguing using humor, instead, meant that the host first told the audience why something was factually, logically, or morally wrong and then argued—periodically applying humor—why this was the case (Zareff 2012). This strategy is also commonly used by John Oliver in LWT.

A journalistic genre entails certain interlinked epistemic ideals, work routines, and modes of presentation (Hermann 2016). One cornerstone in modern news journalism has traditionally been the ideal of objectivity (e.g., Schudson 2001). Nowadays a contested concept, objectivity can be understood "pragmatically" as processes toward an unattainable objective truth by overcoming-as much as it is possible in a certain context—fallacies and prejudices of human interpretation (e.g., Ward 2004). Even though Nordic news satirists did not express a straightforward striving for "objectivity," some of the key dimensions of objectivity were reinterpreted. According to Westerståhl (1983), objectivity can be divided into factuality and impartiality. Factuality further entails relevance and truthfulness, and impartiality includes balance and neutrality. Most of the interviewed satirists emphasized factuality as an important aim. There was a sense of pride connected to presenting correct facts, especially in the main sections of the shows. Accordingly, the work routines entailed fact-checking from several sources such as news archives, official reports, and press releases. This process was compared to topical and investigative reporting in that it focused on exposing 
hypocrisy and systemic wrongdoings (Fox 2018; Lockyer 2006). The teams also gathered material on recurring issues, pondering the right time to do a story. Working in this manner allowed for grasping longer processes and subject areas, for which there was less and less time in traditional journalism due to cutbacks and an increased tempo in the news cycle.

Furthermore, the team members consulted older colleagues and special journalists for confirming the relevance and justification for their satirical critique. If a critical hunch or an intuition was proven to be groundless, the team would ditch it and find another angle. They believed that their humor worked because it was based on truth. Even if they were doing "just" satire, being caught with incorrect information would be cause for embarrassment and detrimental to credibility.

Although exaggeration is absolutely allowed and necessary, so that things will be funny, the core has to be somewhat honest. That's why we don't want to, for example, take two words by a person out of context and then attack him/her for five minutes because of it; it's not fair. (FPS3)

Impartiality was never a central aim for those interviewed. They did not believe that pure impartiality or neutrality was even possible, let alone in a format that was based on exaggeration. One team member expressed that the difference from being in a traditional newsroom was that instead of showing a smorgasbord of political positions and facts, all equally stated, the satirist had a clear point of view. Moreover, the journalistic practice of inviting studio guests to respond to critique, or to give rebuttal in a debate, was said to be detrimental to comedy. Unlike in TDS, they did not invite politicians onto their shows as guests. One reason mentioned for this was an unwillingness to give them a platform for self-promotion.

Regarding the satirists' political views, different team members from the same production crew could have contrasting opinions on certain issues, and these were debated during the work process. These spats were, however, mostly seen as separate from party politics. The satirists did not think their work reflected a certain political agenda, and thus would likely reject a term such as advocacy satire (Waisanen 2018), though they believed that their core values to some degree affected the content. News satirists' ethical ground thus resembles some of the reform programs in journalism, according to which neutrality does not hold when it comes to universally understood values such as peace, human rights, and democracy (Carpentier 2005).

A perfect balance was indeed seen as impossible to achieve in news satire. It did not matter which political party the target of satire would represent if she/he had given the grounds for critique. Nevertheless, at times, the teams pondered their overall balance. The fact that two of the shows are public service broadcasting productions puts institutional expectations in place and sets certain boundaries for the conduct. Particularly this meant maintaining a neutral bias over time and speaking to a broad audience. Some of the interviewed satirists mentioned explicit strategies to ensure that jabs were evenly distributed across the political spectrum. Sometimes shows would do a review, and if they concluded that they had not talked about a 
specific party for three shows, then they had to start looking for some issue to raise there. There were however differing views on balance even within the same show. The dispute was that counting targets per episode would not be a valid or practical method, and instead one should aim for an equal distribution of political mockery over time. For some, being partial was not inherently wrong as long as you had "your facts straight" (SPSB5).

The satirists particularly expressed a desire to deal with politics and societal issues in their shows. Moreover, similar to current affairs programs and magazine articles, their main sections employed a thematic framing rather than the episodic approach that is more common in short news flashes. Altogether, this would support a view of Nordic news satire as a hard news genre. However, when assessing news satirists' perceptions of style dimensions, we get a different perspective. The interviewed satirists expressed that they aim for an emotional and personal style, finding it both liberating and more captivating to audiences. This kind of style was compared to discussions over a drink with close colleagues or friends, creating a more intimate relationship between the host and the audience than in regular news reporting. This gives the genre qualities generally ascribed to soft news (Otto, Glogger, and Boukes 2017; Reinemann et al. 2012).

Common targets of satire are those in power, societal and cultural practices, and general human vices such as greed, hypocrisy, stupidity, laziness, and superficiality (Griffin 1994; Kivistö 2007). The Nordic satirists stressed that they mostly aim to criticize the powerful actors in society like the government, big businesses, unions, influencers, and juridical persons. Their approach was often to criticize the language and framing used by the powerful. Mockery did not usually involve regular citizens or marginal groups, as punching down was seen as inappropriate. This coincided with the explicit aims of Jon Stewart who, on taking over TDS, began shifting the show toward targeting power (Smith 2016). However, in addition to punching up, there was also an expressed desire to punch inwards, meaning to scrutinize the habits and ideals of the middle class.

The interviewed satirists were hesitant to present themselves as powerful. Instead they stressed having little to no effect on actual political decisions. They believed they could have some effect on people's impressions of some issues or persons, but little direct influence on public opinion at large. They hoped to be able to expose hypocrisies and unfold the often-long processes of political decision making and power struggles in an easily understandable manner. They saw themselves as capable of providing new perspectives to public debate, and through humor create aha-moments and new discussions.

I mostly want to enlighten people about things that exist. And are true. And then I hope they themselves understand why that is something either wrong or upsetting or great and you should be happy about it. But directly influencing people? No. (SPSB1) 
In summary, the interviewees recognized to a large extent the journalistic aspects of their work. One jokingly called satire "a mix of bad comedy and bad journalism": not funny enough to be considered comedy and not substantial enough to be journalism. "But if you don't have a cynical attitude like that, the thing with satire, when it's really good, it needs to be comedy with journalistic qualities. It has to be both." (SC6).

\section{Conclusions and Discussion}

In this article, we explored the aims and work routines of Nordic news satirist through the concepts of genre and boundary work. Based on 16 interviews with team members from four journalistic news satire productions, we analyzed how they relate their programs to traditional news journalism and other forms of satire. In particular we showed how Finnish and Swedish journalistic news satirists established boundaries between their work and traditional news journalism and to other satire in their countries. Accordingly, their programs were differentiated from news journalism and compared to culture journalism or opinion journalism, using a personal and more emotional presentation as in a column, essay, or debate. However, their programs were perceived as similar to news journalism in that they included politically current main stories with factual contextualization equivalent to any topical journalistic piece. Based on this journalistic output, the satirists also differentiated their programs from previous Finnish and Swedish satire, which was perceived as shallower, often based on mere carnivalization of politics with little to no substance.

Secondly, we focused on how news satire is similar to and different from news journalism in its aims and work routines. The most prevalent aim for journalistic news satirists was to provide factually based critical insights on topical issues in an entertaining and easily understandable manner. The satirists believed this was possible due to a unique mix of professional journalists and comedians working toward the same goal. The work routines included observing the daily news flow of traditional media and subsequently participating in it —or providing alternatives to it - through satirical takes. The teams engaged in journalistic data collection and source criticism and combined it with different humor techniques like comparisons, neologisms, irony, and hyperbole. Through these combinations they attempted to give more thematic contextualization to topical societal issues than was possible in individual news pieces. In this sense, journalistic news satire seemed like a hard news genre (Otto, Glogger, and Boukes 2017; Reinemann et al. 2012). However, the format provided room for a more emotional, personal, and exaggerated style than in traditional news journalism, thus also resembling soft news (Reinemann et al. 2012).

There were striking similarities between the Finnish and Swedish satirists, showing a fairly united perception of their work. Partly the similarities could be explained by the heavy influence of North American role models. In addition, they were all embedded in the Nordic context, mostly sharing a string of foundational values, beliefs, and relations to political and media systems (Hallin and Mancini 2004). Moreover, many of 
the team members had educational and/or professional background in journalism, which provided a relatively stable set of ideals and routines for work culture. Overall, our analysis supports the view that journalists seem to hold on to some of the absorbed professional values and routines as they move on to more entertaining formats (Bolin 2014).

Furthermore, our findings contribute to the understanding of news satire as a new journalistic genre (Baym 2005; Faina 2012; Fox 2018; Hersey 2013; Peters 2013; Young 2012). Our analysis indicates how news satirists themselves engage in boundary work to differentiate their shows from news journalism and from previous satire. This clarifies, and perhaps justifies, the genre status of The Daily Show type of satire as a form of journalistic news satire. It seems that Nordic news satirists indeed embrace the envisioned neomodern ethos (Baym 2010), meaning they simultaneously hail some of the modern journalistic ideals such as the striving for factuality, relevance, and monitoring the powerful, but they also embrace some of the postmodern aesthetic features such as irony, play, and constant allusions.

Emerging infotainment genres are important topics of analysis, as they can broaden our thoughts and action horizons in relation to producing journalism. Journalistic news satire is a peculiar type of infotainment with a unique mix of substantial contextualization and satiric insight. By working together, journalists and professional comedians can provide popularized policy and media critique to the public sphere. In the US, under the baton of LWT, this critically acclaimed and popular type of satire seems to be evolving toward investigative (Fox 2018) and advocacy journalism (Kilby 2018; Waisanen 2018). In the Nordic context, journalistic news satire is a rather new genre. In Finland, its first adaptations were relatively short-lived (2014-2017), although quite successful (Koivukoski 2019). In Sweden, the TV show modeled after LWT has to date aired for four seasons, and the genre has in addition expanded to podcast format (Ödmark 2018). The Nordic productions analyzed were like mixes of TDS and LWT: they appeared weekly like LWT, and shared a similar ambition and aims, but did not have the same resources for investigative work.

In conclusion, our peek backstage into journalistic news satire production complements the view of the genre that has so far been mostly based on media system, content, and audience analysis. As journalistic news satire spreads across the world, future research could further compare similarities and differences in production, content, effects, and audiences in different contexts. From the perspective of democracy theory, the ironic and factually grounded insights into topical issues provided by news satire programs broaden the narrative forms through which politics is discussed and understood, making it an important topic for investigation. Future work could also analyze political underpinnings of the genre, and bordering genres. While most of the journalistic news satire in the US has had a broadly liberal outlook, humor is also a common tool for conservative media personalities and activists. Recent work has suggested that the style of 'outrage' in this kind of programming uses forms of humor such as hyperbole and pejorative nicknames to connect with audiences (Young 2019). Moreover, online interaction on forums and social media often mixes 
humor and politics in various ways. Political entertainment scholars should therefore continue to expand the genres, mediums, and types of actors that they include in their studies. One can predict that humor will continue to play a pivotal role in political identity projects in the years to come.

\section{References}

Baumgartner, Jody, and Jonathan Morris. 2006. "The Daily Show Effect: Candidate Evaluations, Efficacy, and American Youth." American Politics Research 34 (3): 341-367. https://doi.org/10.1177/1532673X05280074

Baym, Geoffrey. 2005. "The Daily Show: Discursive Integration and the Reinvention of Political Journalism." Political Communication 22 (3): 259-276. https://doi.org/10.1080/10584600591006492

Baym, Geoffrey. 2010. From Cronkite to Colbert: The Evolution of Broadcast News. Boulder, CO: Paradigm Publisher.

Berkowitz, Dan, and Robert Gutsche. 2012. "Drawing Lines in the Journalistic Sand: Jon Stewart, Edward R. Murrow, and Memory of News Gone By." Journalism \& Mass Communication Quarterly 89 (4): 643-656.https://doi.org/10.1177/1077699012456020

Bolin, Göran. 2014. "Television Journalism, Politics, and Entertainment: Power and Autonomy in the Field of Television Journalism." Television \& New Media 15 (4): 336-349. https://doi.org/10.1177/1527476414525671

Boukes, Mark. 2018. “Agenda-setting with Satire: How Political Satire Increased TTIP's Saliency on the Public, Media, and Political Agenda." Political Communication (Online First), 1-26. https://doi.org/10.1080/10584609.2018.1498816

Boukes, Mark. 2019. “Infotainment.” The International Encyclopedia of Journalism Studies, 1-9. https://doi.org/10.1002/9781118841570.iejs0132

Brewer, Paul, and Emily Marquardt. 2007. "Mock News and Democracy: Analyzing The Daily Show." Atlantic Journal of Communication 15 (4): 249-267. https://doi.org/10.1080/15456870701465315

Bruun, Hanne. (2010). Genre and interpretation in production: a theoretical approach. Media, Culture \& Society, 32 (5): 723-737.

Bruun, Hanne. 2012. "Political Satire in Danish Television: Reinventing a Tradition." Popular Communication 10 (1-2):158-169.

Carlson, Matt. 2016. "Metajournalistic Discourse and the Meanings of Journalism: Definitional Control, Boundary Work, and Legitimation." Communication Theory 26 (4): 349-368. https://doi.org/10.1111/comt.12088

Carpentier, Nico. 2005. "Identity, Contingency and Rigidity: The (Counter-) Hegemonic Constructions of the Identity of the Media Professional." Journalism 6 (2): 199-219. https://doi.org/10.1177/1464884905051008

Condren, Conal. 2012. "Satire and Definition." Humor 25 (4): 375-399. https://doi.org/10.1515/humor2012-0019

Dagnes, Alison. 2012. A Conservative Walks into a Bar: The Politics of Political Humor. New York: Springer.

Doona, Joanna. 2016. Political Comedy Engagement: Genre Work, Political Identity and Cultural Citizenship. Lund University: Avdelningen för medie- och kommunikationsvetenskap.

Druick, Zoë. 2009. "Dialogic Absurdity: TV News Parody as a Critique of Genre." Television \& New Media 10 (3): 294-308. doi:10.1177/1527476409332057.

Edgerly, Stephanie. 2017. "Making Sense and Drawing Lines: Young Adults and the Mixing of News and Entertainment." Journalism Studies 18 (8): 1052-1069. https://doi.org/10.1080/1461670X.2015.1100522

Faina, Joseph. 2012. "Public Journalism Is a Joke: The Case for Jon Stewart and Stephen Colbert." Journalism 14 (4): 541-555. doi:10.1177/1464884912448899. 
Feldman, Lauren. 2007. "Young Audiences, The Daily Show, and Evolving Notions of Journalism." Journalism 8 (4): 406-427. https://doi.org/10.1177/1464884907078655

Feldman, Lauren. 2013. "Learning about Politics from The Daily Show: The Role of Viewer Orientation and Processing Motivations." Mass Communication and Society 16 (4): 586-607. https://doi.org/10.1080/15205436.2012.735742

Fox, Julia, Glogy Koloen, and Volkan Sahin. 2007. "No Joke: A Comparison of Substance in The Daily Show with Presidential Election Campaign." Journal of Broadcasting \& Electronic Media 51 (2): 213-227. https://doi.org/10.1080/08838150701304621

Fox, Julia. 2018. "Journalist or Jokester?" In Political Humor in a Changing Media Landscape: A New Generation of Research, edited by Jody Baumgartner and Amy Becker, 29-44. Lanham, MD: Lexington Books.

Fox, Julia R., and Edo Steinberg. 2019. "News You Can't Use: Jon Stewart's Daily Show Media Critiques." Journalism \& Mass Communication Quarterly. (Online First) doi:10.1177/1077699019851228.

Gieryn, Thomas. 1983. "Boundary-work and the Demarcation of Science from Non-science: Strains and Interests in Professional Ideologies of Scientists." American Sociological Review 48 (6): 781-795. https://www.jstor.org/stable/2095325

Gray, Jonathan, Jeffrey Jones, and Ethan Thompson. 2009. Satire TV: Politics and Comedy in the PostNetwork Era. New York: NYU Press.

Griffin, Dustin. 1994. Satire: A Critical Reintroduction. Lexington, KY: University Press of Kentucky.

Hallin, Daniel C., and Paolo Mancini. 2004. Comparing Media Systems: Three Models of Media and Politics, Communication, Society, and Politics. New York, NY: Cambridge University Press.

Hart, Roderick, and Johanna Hartelius. 2007. "The Political Sins of Jon Stewart." Critical Studies in Media Communication 24 (3): 263-272. https://doi.org/10.1080/07393180701520991

Hermann, Anne. 2016. “Ethnographic Journalism.” Journalism 17 (2): 260-278. https://doi.org/10.1177/1464884914555964

Hersey, Curt. 2013. Nothing but the Truthiness: A History of Television News Parody and Its Entry into the Journalistic Field. Atlanta, GA: Georgia State University.

Jones, Jeffrey. 2010. Entertaining Politics: Satiric Television and Political Engagement. Lanham, MD: Rowman \& Littlefield Publishers.

Kilby, Allaina. 2018. "Provoking the Citizen.” Journalism Studies 19 (13): 1934-1944, doi:10.1080/1461670X.2018.1495573

Kivistö, Sari 2007. Satiiri kirjallisuuden lajina. In Satiiri. Johdatus lajin historiaan ja teoriaan, edited by Sari Kivistö. Helsinki: Yliopistopaino, 9-26.

Koivukoski, Joonas, and Janne Zareff. 2018. Scatological Anecdotes, Heavy Drinking, and Backpacker Culture: Gonzo Humor and Edgework in Contemporary Finnish Journalism. In Fear and Loathing Worldwide: Gonzo Journalism Beyond Hunter S. Thompson, edited by Robert Alexander and Christine Isager, 225-242. New York, NY: Bloomsbury Academic.

Koivukoski, Joonas. 2019. "Journalistinen uutissatiiri hybridinä genrenä: Noin viikon uutisten ja Uutisraportin tekijöiden itseymmärrys ja käsitteellinen rajatyö.” Media \& viestintä 42 (1): 2646. https://doi.org/10.23983/mv.80181

Lamont, Michèle, and Virag Molnár. 2002. "The Study of Boundaries in the Social Sciences." Annual Review of Sociology 28 (1): 167-195. https://doi.org/10.1146/annurev.soc.28.110601.141107

Lamont, Michèle, and Ann Swidler. 2014. "Methodological Pluralism and the Possibilities and Limits of Interviewing." Qualitative Sociology 37 (2): 153-171.

Lockyer, Sharon. 2006. “A Two-Pronged Attack? Exploring Private Eye's Satirical Humour and Investigative Reporting." Journalism Studies 7 (5): 765-781.

Mäntynen, Anne, and Susanna Shore. 2014. "What Is Meant by Hybridity? An Investigation of Hybridity and Related Terms in Genre Studies." Text \& Talk 34 (6): 737-758. https://doi.org/10.1515/text2014-0022

Ödmark, Sara. 2018. "Making News Funny: Differences in News Framing between Journalists and Comedians." Journalism. (Online First)_https://doi.org/10.1177/1464884918820432

Otto, Lukas, Isabella Glogger, and Mark Boukes. 2017. "The Softening of Journalistic Political Communication: A Comprehensive Framework Model of Sensationalism, Soft News, Infotainment, and Tabloidization." Communication Theory 272, 136-155.https://doi.org/10.1111/comt.12102

Patton, Michael. 1980. Qualitative Evaluation Methods. Beverly Hills, CA: Sage Publications. 
Peifer, Jason, and Taeyoung Lee. 2019. "Satire and Journalism." In Oxford Research Encyclopedia of Communication. doi:10.1093/acrefore/9780190228613.013.87

Peters, Chris. 2013. Even Better than Being Informed. Satirical News and Media Literacy. In Rethinking Journalism. Trust and Participation in a Transformed News Landscape, edited by Marcel Broersma and Chris Peters, 173-188. New York: Routledge.

Pew Research Center. 2008. Journalism, Satire, or Just Laughs? "The Daily Show with Jon Stewart”, Examined. https://www.journalism.org/2008/05/08/journalism-satire-or-just-laughs-the-daily-showwith-jon-stewart-examined/ (retrieved 21.3.2019).

Reckwitz, Andreas. 2002. "Toward a Theory of Social Practices: A Development in Culturalist Theorizing." European Journal of Social Theory 5 (2): 243-263. https://doi.org/10.1177/13684310222225432

Reinemann, Carsten, James Stanyer, Sebastian Scherr, and Guido Legnante. 2012. "Hard and Soft News: A Review of Concepts, Operationalizations and Key Findings." Journalism 13 (2): 221-239. https://doi.org/10.1177/1464884911427803

Rottinghaus, Brandon, Kenton Bird, Travis Ridout, and Rebecca Self. 2012. "It's Better than Being Informed," College-aged Viewers of The Daily Show. In Laughing Matters: Humor and American Politics in the Media Age, edited by Jody Baumgartner and Jonathan Morris, 279-294. New York: Routledge.

Schudson, Michael. 2001. "The Objectivity Norm in American Journalism.” Journalism 2 (2): 149-170.

Schultz, Ida. 2007. "The Journalistic Gut Feeling: Journalistic Doxa, News Habitus and Orthodox News Values." Journalism Practice 1 (2): 190-207.https://doi.org/10.1080/17512780701275507

Smith, Chris. 2016. The Daily Show (The Book): An Oral History as told by Jon Stewart, the Correspondents, Staff and Guests. New York, NY: Grand Central Publishing.

Tenenboim-Weinblatt, Keren. 2009. "Jester, Fake Journalist, or the New Walter Lippmann? Recognition Processes of Jon Stewart by the US Journalistic Community." International Journal of Communication 3 (2009): 416-439.

Valaskivi, Katja. 2002. Leipää ja rinkeliä: johdatus asian ja viihteen suhteeseen suomalaisessa televisiossa. Tampere: University of Tampere.

Waisanen, Don J. 2018. "The Rise of Advocacy Satire.” In Political Humor in a Changing Media Landscape: A New Generation of Research, edited by Jody Baumgartner and Amy Becker, 11-29. Lanham, MD: Lexington Books.

Ward, Stephen J. 2004. The Invention of Journalism Ethics. The Path to Objectivity and Beyond. Montreal: McGill-Queen's University Press.

Westerståhl, Jörgen. 1983. Objective News Reporting: General Premises. Communication Research 10 (3): 403-424. https://doi.org/10.1177/009365083010003007

Wiesman, Penina. 2011. We Frame to Please: A Preliminary Examination of The Daily Show's Use of Frames. In The Daily Show and Rhetoric: Arguments, Issues and Strategies, edited by Trischa Goodnow, 131-151. Lanham, MD: Lexington Books.

Young, Dannagal. 2012. "The Daily Show as the New Journalism: In Their Own Words. In Laughing Matters: Humor and American Politics in the Media Age, edited by Jody Baumgartner and Jonathan Morris, 265-284. New York: Routledge.

Young, Dannagal, and Lindsay Hoffman. 2012. "Acquisition of Current-Events Knowledge from Political Satire Programming: An Experimental Approach.” Atlantic Journal of Communication 20 (5): 290304. doi:10.1080/15456870.2012.728121

Young, Dannagal. 2019. Irony and Outrage: The Polarized Landscape of Rage, Fear, and Laughter in the United States. New York: Oxford University Press.

Zareff, Janne. 2012. Journalistinen komiikka: teoreettisia ja käytännöllisiä avauksia. Jyväskylä Studies in humanities n. 18. 